\title{
SUPPRESSION OF HETEROLOGOUS IMMUNITY BY NEMATOSPIROIDES DUBIUS ANTIGENS IN VITRO
}

\author{
C. Crawford, J. M. Behnke and D. I. Pritchard \\ MRC Experimental Parasitology Unit, Department of Zoology, University of Nottingham, University Park, Nottingham \\ NG7 2RD, U.K.
}

(Received 20 July 1987; accepted 15 July 1988)

\begin{abstract}
Crawford C., Behnke J. M, and Pritchard D. I. 1989. Suppression of heterologous immunity by Nematospiroides dubius antigens in vitro. International Journal for Parasitology 19: 29-34. The direct effect of the soluble antigens in the homogenate of adult Nematospiroides dubius (AH) on spleen cells from uninfected NIH mice was investigated using a Mishell-Dutton culture system. Parasite antigens were shown to reduce the plaque-forming cell (PFC) response to sheep red blood cells (SRBC) in a dosedependent manner in vitro. A population of suppressor cells was demonstrated in the spleens of infected mice. Furthermore naive spleen cells cultured in the presence of $\mathrm{AH}$ gave rise to cells which depressed the PFC response of naive cells when subsequently cultured together in vitro. Treatment of these cell populations with anti-thy 1.2 plus complement did not impair suppressor activity, and it was concluded that cells expressing the T-cell phenotype were not involved.
\end{abstract}

INDEX KEY WORDS: Nematospiroides dubius; plaque forming cells (PFC); sheep red blood cells (SRBC); suppressor cells.

\section{INTRODUCTION}

THE trichostrongyle nematode Nematospiroides dubius survives in the mouse small intestine for 8 months or more in a primary infection (Ehrenford, 1954; Keymer \& Hiorns, 1986), and exerts a depressive effect on the host's ability to respond to heterologous (Chowaniec, Wescott \& Congdon, 1972; Shimp, Crandall \& Crandall, 1975; Price \& Turner, 1986a, b) and homologous antigens (Pritchard \& Behnke, 1985; Sitepu, Dobson \& Brindley, 1985). In mice concurrently infected with $N$. dubius and $T$. spiralis, the survival time of the latter parasite is prolonged compared to controls (Behnke, Wakelin \& Wilson, 1978). A primary infection with $N$. dubius is also known to severely depress the host's immune response to concurrently administered sheep erythrocytes (Shimp et al., 1975; Ali \& Behnke, 1983), and it can be demonstrated that the degree of suppression is a function of the number of adult worms present in the small intestine (Ali \& Behnke, 1983). Suppression has also been shown to be maximal 14 days after infection, corresponding to the presence of the adult stage in the lumen, rather than the $\mathrm{L} 4$ stage which resides in the gut wall (Ali \& Behnke, 1983). It has been proposed that $N$. dubius facilitates its own survival in the gastrointestinal tract in the face of an immune response by the production of immunomodulatory factors (Behnke, Hannah \& Pritchard, 1983; Behnke, 1987) which may also be implicated in suppression of heterologous immunity. Thus mice given a normally immunogenic infection with irradiated larvae at the same time as an infection with normal larvae do not become immune to challenge (Behnke et al., 1983), and homologous immunity stimulated by an anthelmintic abbreviated infection is reduced on injection with soluble adult antigen (Pritchard \& Behnke, 1985), as is the response to the heterologous antigen, sheep red cells (SRBC) (Pritchard, Ali \& Behnke, 1984).

The present study was designed to confirm and expand these in vivo observations by utilizing a Mishell-Dutton culture system, in which normal splenocytes are stimulated in vitro with $\mathrm{SRBC}$, and their responsiveness assessed in a plaque (PFC) assay. This system is advantageous in that it has proven to be more manipulable than in vivo systems, and requires significantly less material to modulate immune responsiveness.

\section{MATERIALS AND METHODS}

Animals. Female NIH mice, 6-8 weeks old, bred under conventional animal house conditions, were chosen for this study following the demonstration that this strain was responsive to sheep erythrocytes using an in vitro MishellDutton culture system.

Antigens. Nematode antigens were prepared as described previously (Pritchard, Williams, Behnke \& Lee, 1983) and filter sterilized prior to use. Sheep erythrocytes were kindly supplied by Mr Walker, School of Agriculture, Nottingham University, Sutton Bonington. Anti-Thy-1.2 was obtained from Serotec Ltd, Blackthorn, Bicester, England. The optimum dose for complement mediated cytotoxicity of $99 \%$ of cells was predetermined using NIH mouse thymocytes, and was subsequently used at a concentration of 
1/1000. Low toxicity rabbit complement was obtained from Cederlane Laboratories Ltd, Hornby, Ontario, Canada, and used at a dilution of 1 in 12 .

In vitro culture. An in vitro assay to analyse the immunorcgulatory effect of $N$. dubius antigens was developed essentially as described by Mishell \& Dutton $(1966,1967)$. Briefly, spleen cells from female NIH mice were resuspended in RPMI 1640 medium supplemented with $5 \%$ fetal calf serum and antibiotics ( 100 i.u. per $\mathrm{ml}$ penicillin and $100 \mu \mathrm{g}$ per ml streptomycin) to give a final concentration of $1 \times 10^{7}$ cells per ml. To each well of the tissue culture tray $0.5 \mathrm{ml}$ of this suspension was added, together with $0.5 \mathrm{ml}$ of the parasite antigen at the required concentration, or with $0.5 \mathrm{ml}$ of the second cell population (see results). The cultures were then inoculated with $30 \mu$ of a $1 \%$ suspension of sheep erythrocytes, and incubated at $37^{\circ} \mathrm{C}$ in a humidified $\mathrm{CO}_{2}$ incubator for 4 days. After this time, the cells were harvested and assayed for the presence of direct (IgM) plaque forming cells against sheep erythrocytes using Cunningham's method (Cunningham, 1965). Results are expressed as the number of PFC/ $10^{6}$ lymphocytes \pm 1 S.D.

Cell counts. Cell viability was determined by using fluorescein diacetate (Mishell \& Mishell, 1980).

\section{RESULTS}

The effect of infection with $\mathrm{N}$. dubius on the immune response of spleen cells to $S R B C$ in vitro

Female NIH mice were infected with 250 L3 larvae of $N$. dubius on day 0 of the experiment, and their spleens removed on days $6,9,15$ and 20 post infection. The responsiveness of single cell suspensions prepared from the spleens to SRBC was then assayed in vitro. Unchallenged cultures were tested in parallel.

From the data in Fig. 1 it can be seen that the immune responsiveness of the cell suspensions diminished as the infection progressed through the larval stages to adulthood on day 9. Furthermore, splenocytes from mice harbouring adult parasites (days 9-21) when co-cultured with naive cells from uninfected animals reduced the latter cell population's responsiveness to sheep erythrocytes in vitro.

The effect of adding the soluble antigens from the homogenate of adult $\mathrm{N}$. dubius on the in vitro immune response of normal splenocytes to $S R B C$

Normal splenocytes were inoculated with SRBC in the presence of $N$. dubius $\mathrm{AH}$ and their ability to respond was assessed 4 days later in a direct PFC assay. In addition, splenocytes cultured in the presence of $\mathrm{AH}$ for 4 days were washed thoroughly to remove any extraneous antigen, transferred to naive cell cultures, and their ability to suppress the SRBC response of the naive cell population was investigated.

Table 1 demonstrates that soluble adult worm antigens could directly reduce the number of PFC in inoculated cultures in a dose-dependent manner. Therefore the higher the dose of $N$. dubius antigen added to the cultures, the greater the suppression of the PFC response observed, compared to cultures

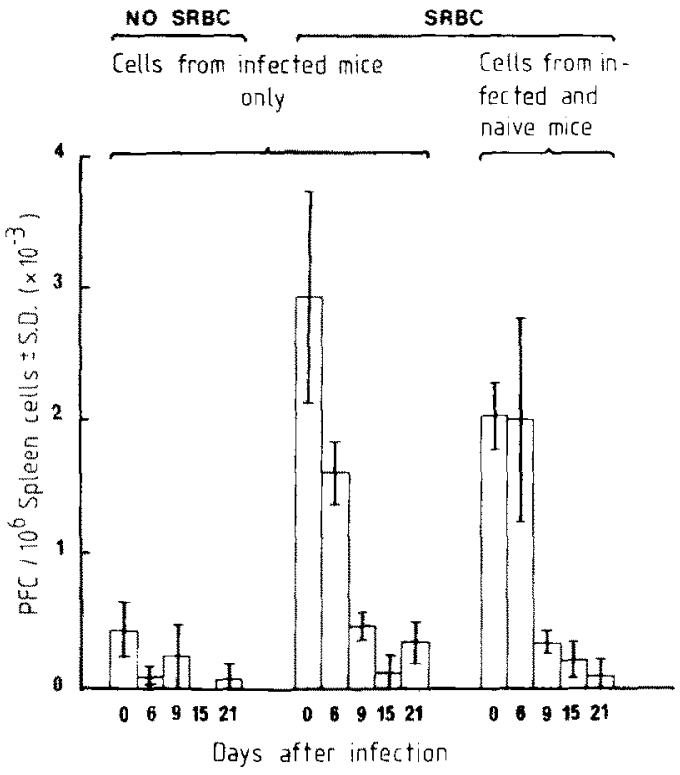

FIG. 1. In vitro response to SRBC of spleen cells from mice infected with $N$. dubius for varying periods of time and the effect of these cells on splenocytes from uninfected animals. $5 \times 10^{6}$ cells from mice infected for different periods of time were cultured in vitro with $30 \mu$ of $1 \%$ SRBC (immunized controls) or without sheep erythrocytes (unstimulated controls). Additionally, cells from infected mice were coincubated with $5 \times 10^{6}$ cells from naive mice together with SRBC. Four days after initiation of cultures, the cells were harvested and PFC assay carried out.

receiving only sheep erythrocytes. However, the degree of suppression varied between experiments for a defined quantity of adult antigen, possibly because of differences in the batches of fetal calf serum and SRBC. The crude worm homogenate caused suppression in this system, without any noticeable toxic effect on cells (as measured by viability), even when used at high concentrations.

This result was explored further to investigate effector cells in this system, and the data in Table 2 confirm that addition of adult antigen to splenocyte cultures reduced the number of PFC observed to sheep erythrocytes compared to controls. When normal spleen cells were incubated with $10 \mu \mathrm{g}$ of AH for 4 days and then added to naive cell cultures together with SRBC, the PFC response was reduced. It appears that the greater the number of $\mathrm{AH}$-treated cells added, the more the PFC were suppressed. Supernatants taken from cells incubated with adult antigen did not reduce the ability of normal splenocytes to respond to $S R B C$.

The effect of adding soluble adult worm antigens to spleen cell cultures at different time intervals after stimulation by $S R B C$

Normal splenocytes were incubated with SRBC in Mishell-Dutton cultures on day zero (A). Fifty 
Table $1-$ The effect of soluble antigens from the homogenate of adult $N$. dubius on the in vitro tmmune Response OF NORMAL SPLENOCYTES TO SRBC

\begin{tabular}{lccc}
\hline & \multicolumn{3}{c}{$\begin{array}{c}\text { PFC/106 cells } \pm 1 \text { s.D. } \\
\text { (\% of immunized control) }\end{array}$} \\
\cline { 2 - 4 } $\begin{array}{l}\text { Antigen added to tissue } \\
\text { culture tray well }(\mu \mathrm{g} / \text { well) }\end{array}$ & Experiment $(1)$ & Experiment $(2)$ & Experiment (3) \\
\hline SRBC alone (immunized control) & $1625 \pm 683$ & $731 \pm 212$ & $1053 \pm 210$ \\
None (unstimulated control) & $130 \pm 25(8)$ & $54 \pm 45(7)$ & $111 \pm 150(10)$ \\
SRBC $+1 \mu \mathrm{g}$ adult homogenate & $1200 \pm 75(74)$ & $576 \pm 87(79)$ & $678 \pm 280(64)$ \\
SRBC $+10 \mu$ gadult homogenate & $1050 \pm 311(65)$ & $532 \pm 115(73)$ & $275 \pm 220(26)$ \\
SRBC $+100 \mu$ g adult homogenate & $407 \pm 185(25)$ & $210 \pm 64(29)$ & $139 \pm 13(13)$ \\
\hline
\end{tabular}

${ }^{*}$ Each well contained $5 \times 10^{\kappa}$ spleen cells from uninfected female NIH mice.

microgrammes of $N$. dubius adult antigen was then added to separate cultures, either at the same time (C) as the sheep erythrocytes, or 1 (D), 2 (E) or 3 (F) days later. Four days after initiation of the experiment, the cells were harvested and assessed for antibody by the PFC assay.

The results in Fig. 2 demonstrate that the addition of adult antigen concurrently with SRBC suppressed the PFC response of the splenocytes to the latter antigen. Suppression was detected irrespective of whether $\mathrm{AH}$ was added on days $0,1,2$ or 3, although the degree of suppression decreased with the increasing interval between the introduction of SRBC and adult antigen to the cultures.

\section{Effect of incubating AH-treated cells with anti-Thy 1.2 plus complement}

Spleen cells from normal NIH mice were incubated for 4 days either in medium alone or with $10 \mu \mathrm{g} \mathrm{AH}$, after which time they were harvested and washed three times to remove any extraneous antigen. Half of the AH-treated splenocytes were then incubated with anti-Thy 1.2 plus complement to remove any $\mathrm{T}$-cells which were present. The three cell populations were added to naive spleen cell cultures together with $\mathrm{SRBC}$, and the PFC response was assessed.

Figure 3 shows that spleen cells treated with $N$. dubius adult homogenate when added to normal splenocytes reduced the PFC response of the latter cell population to SRBC. However, prior incubation of antigen treated spleen cells with anti-Thy 1.2 plus complement did not restore the PFC response to control levels.

\section{DISCUSSION}

The work presented in this paper set out to determine the direct effect of soluble adult $N$. dubius antigen on spleen cell responses to SRBC, in an attempt to understand further the mechanism by which suppression of heterologous immunity operates, and to pave the way for purification of immunomodulatory material from the parasite. Therefore the responsiveness of spleen cells taken from mice at different times after $N$. dubius infection to a heterologous antigen was investigated in vitro. This first experiment (Fig. 1) confirmed the observations that mice harbouring adult worms (days 9-21) were less responsive to $S R B C$ than animals with a larval infection (day 6) (Ali \& Behnke, 1983). Moreover, it was

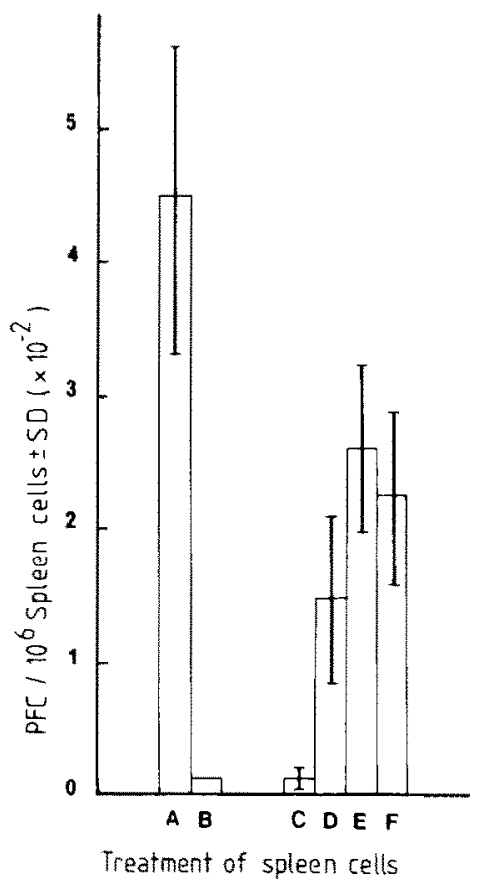

Fig. 2. The effect of adding soluble antigens from the homogenate of adult $N$, dubius (AH) to spleen cells from uninfected mice at different time intervals after stimulation by $\mathrm{SRBC}$ in vitro. $5 \times 10^{6}$ cells from naive mice were incubated with (A-immunized control) or without (Bunstimulated control) $30 \mu \mathrm{l}$ of $1 \%$ SRBC. Splenocytes stimulated by $\mathrm{SRBC}$ in vitro were also cultured in the presence of $50 \mu \mathrm{g}$ of $\mathrm{AH}$, the latter being added to culture wells on day 0 (C), day 1 (D), day 2 (E) or day 3 (F) after initiation of incubation. All the cultures were harvested on day 4 for analysis of PFC. 
TABle 2-The effect of SPLEEN Cells CULTURED IN THE PRESENCE OF SOLUBLE ANTIGENS FroM THE HOMOGENATE OF ADULT $N$. dubius (AH) ON THE IMMUNE RESPONSE OF NORMAL SPLENOCYTES TO SRBC in vitro

\begin{tabular}{lc}
\hline $\begin{array}{l}\text { Antigen and/or cells added } \\
\text { to tissue culture well* }\end{array}$ & $\begin{array}{c}\text { PFC } / 10^{6} \text { cells } \pm 1 \text { s.D. } \\
\text { (\% of immunized well) }\end{array}$ \\
\hline SRBC alone (immunized control) & $1171 \pm 229$ \\
None (unstimulated control) & $356 \pm 96(30)$ \\
SRBC $+0.1 \mu \mathrm{g} \mathrm{AH}$ & $1015 \pm 63(87)$ \\
$\mathrm{SRBC}+1.0 \mu \mathrm{gAH}$ & $950 \pm 77(81)$ \\
$\mathrm{SRBC}+10.0 \mu \mathrm{gAH}$ & $325 \pm 54(27)$ \\
$\mathrm{SRBC}+$ supernatant from $0.1 \mu \mathrm{g} \mathrm{AH} /$ well $\dagger$ & $1008 \pm 118(93)$ \\
SRBC + supernatant from $1.0 \mu \mathrm{g} \mathrm{AH} /$ well & $1499 \pm 232(128)$ \\
SRBC + supernatant from $10.0 \mu \mathrm{g} \Lambda \mathrm{H} /$ well & $1960 \pm 255(157)$ \\
SRBC $+5 \times 10^{6}$ cells from $10.0 \mu \mathrm{g} \mathrm{AH} /$ well $\ddagger$ & 0 \\
SRBC $+1 \times 10^{6}$ cells from $10.0 \mu \mathrm{g} \mathrm{AH} /$ well & $495 \pm 53(42)$ \\
SRBC $+0.5 \times 10^{6}$ cells from $10.0 \mu \mathrm{g} \mathrm{AH} /$ well & $787 \pm 73(67)$ \\
\hline
\end{tabular}

\footnotetext{
*Each well contained $5 \times 10^{6}$ spleen cells from uninfected female NIH mice.

Supernatants were obtained from normal splenocytes cultured in the presence of AH at the concentration shown for 4 days.

$\ddagger$ Cells were obtained from cultures of normal splenocytes incubated with $10 \mu \mathrm{g}$ of AH for 4 days.
}

demonstrated that splenocytes from mice harbouring adult parasites reduced the response of naive spleen cells to sheep erythrocytes, indicating the presence of a suppressor cell population in these animals. Similarly, soluble adult worm antigens were shown to directly reduce the in vitro $\mathrm{PFC}$ response of naive splenocytes in a dose dependent manner (Table 1). This also appeared to be due to a suppressor cell population, since the reduction in plaques of normal cells was a function of the transferred $\mathrm{AH}$-treated cells and not the supernatants (Table 2). Furthermore, a reduction in the $P F C$ response of splenocytes was observed even when adult antigen was added 3 days after inoculation of SRBC into Mishell-Dutton cultures (Fig. 2), indicating the rapid generation and influence of the suppressor cell on the production of IgM antibody to sheep erythrocytes. Treating cells incubated with adult $N$. dubius antigen with anti-Thy 1.2 plus complement to remove all $T$-cells did not eliminate the in vitro generated suppressor cell population, therefore $T$-cells are unlikely to be responsible. This conclusion is supported by the work of Price \& Turner (1986a) who investigated in vivo responses to ovalbumin administered with adjuvant in $N$. dubius infected mice. Variable suppressor activity was identified in spleen cells taken from infected mice transferred to irradiated recipients, which was not mediated by T-cells. However, a role for T-cells in suppression of heterologous immunity has possibly been implicated by the restorative effect of $2^{\prime}$ deoxyguanosine treatment on the immune response of N. dubius infected mice (Pritchard et al., 1984), although macrophage mediated suppression of the proliferative response of thymocytes to concanavalin $A$ in rats can be abolished by 2'-deoxyguanosine, but this has not yet been shown in mice (Bril, van den
Akker, Hussaarts-Odijk \& Benner, 1985). However, suppression is not the property of adult $N$. dubius antigen alone, for day 6 larval antigen was also able to reduce the $\mathrm{PFC}$ response in culture to $\mathrm{SRBC}$, as were homogenates prepared from Necator americanus. Other nematode antigens such as those obtained from Ascaris suum gave different results, actually increasing the PFC response in vitro (personal observations).

Suppressor cells have been implicated as mediators of non-specific suppression to heterologous antigens in other parasitic infections. For example the response of mice infected with T. brucei to SRBC is depressed (Murray, Urquhart, Murray \& Jennings, 1973) and in murine malarial infections of $P$. yoelii and $P$. berghei impairment of humoral responses to sheep erythrocytes was observed (Salaman, Wedderburn \& BruceChwatt, 1969; Greenwood, Playfair \& Torigiani, 1971). Experiments have shown that an excess of normal resident macrophages can profoundly depress lymphocyte proliferation, and if the macrophages are activated, the effect is even more pronounced (Kaufman, Simon \& Hahn, 1982). All stages of N. dubius can activate complement by the alternative pathway (Prowse, Ey \& Jenkin, 1979) so cleaving the complement component $\mathrm{C}_{3}$ into $\mathrm{C}_{3} \mathrm{a}$ and $\mathrm{C}_{3} \mathrm{~b}$ fragments, the latter of which is a potent agent for activating macrophages. Additionally the surface of many nematodes is polyanionic (Himmelhoch \& Zuckerman, 1983; Murrell \& Graham, 1983), a factor which can contribute to the activation of macrophages, and activated macrophages are known to be associated with chronic inflammation, such as occurs during infection with $N$, dubius (see Allison, 1978).

The possibility that a non- $T$ suppressor cell might be involved in the non-specific suppression observed during infection of mice with $T$. brucei was raised by 


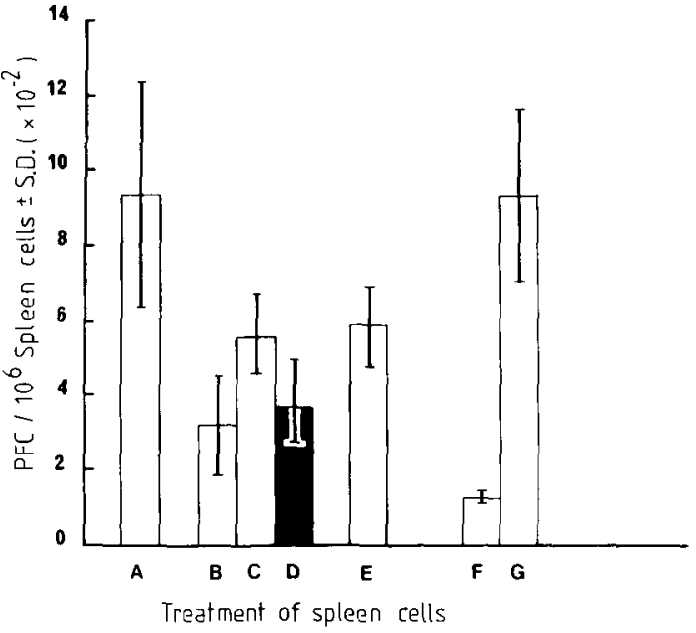

Fig. 3. The effect of anti-Thy $1.2+$ complement on the ability of spleen cells cultured in the presence of the soluble antigens from the homogenate of adult $N$. dubius (AH) to suppress the PFC response of naive splenocytes to SRBC. The experiment comprised the following groups: A. $5 \times 10^{6}$ naive splenocytes $+\mathrm{SRBC}+5 \times 10^{6}$ naive cells after incubation in medium for 4 days. [Naive splenocytes from uninfected mice were incubated in medium without $\mathrm{AH}$ for 4 days but were otherwise treated identically to cells exposed to $\mathrm{AH}$ prior to addition to these cultures.] $\mathrm{B}$. $5 \times 10^{6}$ naive splenocytes $+\mathrm{SRBC}+5 \times 10^{6} \mathrm{AH}$ treated cells. [Naive splenocytes were incubated in the presence of $10 \mu \mathrm{g}$ of $\mathrm{AH}$ for 4 days prior to addition to these cultures.|C. $5 \times 10^{6}$ naive splenocytes $+\mathrm{SRBC}+2.5 \times 10^{6} \mathrm{AH}$ treatcd cells. [Naive splenocytes were incubated in the presence of $10 \mu \mathrm{g}$ of $\mathrm{AH}$ for 4 days prior to addition to these cultures.]. D. $5 \times 10^{6}$ naive splenocytes $+\mathrm{SRBC}+2.5 \times 10^{6} \mathrm{AH}$ treated cells after incubation with anti-Thy $1.2+$ complement. [Naive splenocytes were incubated in the presence of $10 \mu \mathrm{g}$ of $\mathrm{AH}$ for 4 days and were then treated with anti-Thy $1.2+$ complement before addition to these cultures.| $\mathrm{E}$. $5 \times 10^{6}$ naive splenocytes + SRBC $+10 \mu \mathrm{g} \mathrm{AH.} \mathrm{F.} 5 \times 10^{6}$ naive splenocytes [no SRBC: unstimulated controls]. $G$.

$5 \times 10^{6}$ naive splenocytes + SRBC [immunized control].

Murray et al. (1973), who found proliferation of mononuclear phagocytes in the lymphoid organs of infected mice. Corsini, Clayton, Askonas \& Ogilvie (1977) found that macrophages obtained from mice profoundly reduced the ability of normal mouse spleen cells to proliferate and secrete antibody when cultured with lipopolysaccharide (LPS). Eardley \& Jayawardena (1977) also observed the generation of adherent cells, able to depress antibody responses of normal spleen cells, present in spleens of $T$. brucei infected mice. However, other workers (Jayawardena, A. N. 1977. Abstract in Proceedings of the Vth International Congress on Protozoology, p. 72) have suggested that thymus dependent lymphocytes are involved in the generation of non-specific adherent suppressor cells during the course of murine malarial infections, and interactions of T-cells and macrophages have been involved in other suppressive effects, for example of contact sensitivity (Asherson \& Zembala, 1974). It has been postulatcd that the triggering of the release of suppressor factors by macrophages may be antigen specific, while the factors themselves are non-specific (Allinson, 1978).

The significance of the observation that parasitic helminths cause non-specific immunodepression in the host is not clear, but one possibility is that the organisms facilitate their own survival through reducing host immunocompetence (Ogilvie \& Wilson, 1976; Behnke, 1987). However, parasite induced immunosuppression does not always prevent the host from responding to parasite antigens. For example, in Trypanosoma brucei infections, there was no evidence that the parasite caused any significant reduction of antibody responses in acute infections (MacAskill, Holmes, Jennings \& Urquhart, 1981). Furthermore, in the case of $N$. dubius, mice infected with irradiated larvae, which generate good immunity to challenge, have a reduced capacity to respond to SRBC (Ali \& Behnke, 1984). Thus the interrelationship of specific and non-specific immunodepression during $N$. dubius infection is still debatable and their relative importance to parasite survival is controversial.

One possibility may be that the role of immunomodulatory factors secreted by $N$. dubius is principally to incapacitate the host's defences in the intestine in the microenvironment created by the parasite (Pritchard \& Behnke, 1985), and that the systemic non-specific effects are a consequence of this activity (Behnke, 1987). Further analysis of this system should reveal the precise relationship between parasite-specific and non-specific immunodepression in $N$. dubius infected mice, and the survival value of such strategies to the parasite.

Acknowledgements - We would like to thank Professors D. Wakelin and P. N. R. Usherwood for the facilities provided for the work in the Department of Zoology. We are also indebted to Mrs J. Brown for technical assistance and Mr K. Cosgrove for animal maintenance. The support of the Medical Research Council through grants G8328675/T and G8100159/T is also gratefully appreciated.

\section{REFERENCES}

Ali N. M. H. \& Behnke J. M. 1983. Nematospiroides dubius: factors affecting the primary response to $\mathrm{SRBC}$ in infected mice. Journal of Helminthology 57: 343-353.

Ali N. M. H. \& Behnke J. M. 1984. Non-specific immunodepression by larval and adult Nematospiroides dubius. Parasitology 88: 153-162.

Alusson A.C. 1978. Mechanisms by which activated macrophages inhibit lymphocyte responses. Immunological Reviews 40: 3-27.

Asherson G. L. \& Zembala M. 1974. Suppression of contact sensitivity by $\mathrm{T}$-cells in the mouse. Demonstration that suppressor cells act at the effector stages of contact sensitivity and their induction following in vitro exposure to antigen. Proceedings of the Royal Society of London Series $B$ 187: 329-348. 
Behnke J.M., Wakelin D.\& Wilson M.M. 1978. Trichinella spiralis: delayed rejection in mice concurrently infected with Nematospiroides dubius. Experimental Parasitology 46: 121-130.

Behnke J. M., Hannah J. \& Pritchard D. I. 1983. Evidence that adult Nematospiroides dubius impair the immune response of mice to a challenge infection. Parasite Immunology 5: 397-408.

BEHNKE J.M. 1987. Evasion of immunity by nematode parasites causing chronic infections. Advances in Parasitology 26: $1-71$.

Bril. H., Akker Th. W. van den, Hussaarts-Oduk L. M. \& BenNer R. 1985. Differential influence of $2^{\prime}$ deoxyguanosine on the induction and expression of suppressor T-lymphocytes in vivo. Cellular Immunology 90: $531-538$.

Chowaniec W., Wescott R. R. \& Congdon H. 1972. Interaction of Nematospiroides dubius and influenza virus in mice. Experimental Parasitology 32: 33-44.

Corsini A. C., Clayton C., Askonas B. A. \& Ogllvie B. M. 1977. Suppressor cells and the loss of B-cell potential in mice infected with Trypanosoma brucei. Clinical and Experimental Immunology 29: 122-131.

Cunningham A. J. 1965. A method of increased sensitivity for detecting single antibody-forming cells. Nature (London) 207: 1106-1107.

Eardley D. D. \& Jayawardena A. N. 1977. Suppressor cells in mice infected with Trypanosoma brucei. Journal of Immunology 119: 1029-1033.

EHRENFORd F. A. 1954. The life cycle of Nematospiroides dubius Baylis (Nematoda:Heligmosomidae). Joumal of Parasitology 40: 480-481.

Greenwood B. M., Playfair J.H.L. \& Torigiani G. 1971. Immunosuppression in murine malaria. 1. General characteristics. Clinical and Experimental Immunology 8: $467-478$.

Himmelhoch S. \& Zuckerman B. M. 1983. Caenorhabditis elegans: characters of negatively charged groups on the cuticle and intestine. Experimental Parasitology 55: $299-$ 305.

Kaufman S. H. E., Simon M. M. \& Hahn H. 1982, Regulatory interactions between macrophages and $\mathrm{T}$ cell subsets in Listeria monocytogenes-specific $\mathrm{T}$-cell activation. Infection and Immunity 38: $907-913$.

Кечмек A. E. \& Hiorns R. W. 1986. Meligmosomoides polygyrus (Nematoda): the dynamics of primary and repeated infection in outbred mice. Proceedings of the Royal Society of London Series B 229: 47-67.

MacAskill J.A., Holmes P. H., Jennings F.W. \& Urquhart G. M. 1981 . Immunological cleatance of ${ }^{75} \mathrm{Se}^{-}$ labelled Trypanosoma brucei in mice. III. Studies in animals with acute infection. Immunology 43: 691-698.

Mishell B. B. \& Mishell R. I. 1980. Primary immunization in suspension cultures. In: Selected Methods in Cellular Immunology (Edited by Mishell B. B. \& Shigi S. M.), pp. 30-37. Freeman W. H., San Francisco.

Mishel.t. R. I. \& Dutton R. W. 1966. Immunization of normal mouse spleen cell suspensions in vitro. Science 153: $1004-1006$.

Mishell R. I. \& Dutton R. W. 1967. Immunisation of dissociated spleen cell cultures from normal mice. Joumal of Experimental Medicine 126: 423-442.

Murray P. K., Urquhart G. M., Murray M. \& Jennings F. W. 1973. The response of mice infected with $T$. brucei to the administration of sheep erythrocytes. Transactions of the Royal Society of Tropical Medicine and Hygiene 67: 267.

Murrell K. D. \& Graham C. E. 1983. Strongyloides rati and Trichinella spiralis: net charge of epicuticle. Experimental Parasitology 55: 331-339.

OGilvie B. M. \& Wilson R. J. M. 1976. Evasion of the immune response by parasites. British Medical Bulletin 32: 177-181.

Price P. \& Turner K. J. 1986a. Immunological consequences of intestinal helminth infections. Cellular and anamnestic responses to ovalbumin. Australian Journal of Experimental Biology and Medical Science 64: 127-135.

Price P. \& TURner K. J, 1986b. Immunosuppressive effects of extracts of helminthic parasites in C57BL mice. International Joumal for Parasitology 16: 607-615.

Pritchard D. I., Williams D. J. L., Behnke J. M. \& Lee T. D. G. 1983. The role of $\lg G_{1}$ hypergammaglobulinaemia in immunity to the gastrointestinal nematode Nematospiroides dubius. The immunochemical purification, antigen-specificity and in vivo anti-parasite effects of $\mathrm{IgG}_{1}$ from immune serum. Immunology 49: 353-365.

Pritchard D.I., Ali N.M.H.\& Behnke J.M. 1984. Analysis of the mechanism of immunodepression following heterologous antigenic stimulation during concurrent infection with Nematospiroides dubius. Immunology 51: 633-642.

Pritchard D. I. \& Behnke J. M. 1985. The suppression of homologous immunity by soluble adult antigens of Nematospiroides dubius. Journal of Helminthology 59: $251-256$.

Prowse S. J., Ey P. L. \& Jenkin C. R. 1979. Alternative pathway activation of complement by a murine parasitic nematode (Nematospiroides dubius). Australian Joumal of Experimental Biology and Medical Science 57: 459 466.

Salaman M. H., Wedderburn N. \& Bruce-Chwatt L. J. 1969. The immunodepressive effect of a murinc plasmo dium and its interaction with murine oncogenic viruses. Journal of General Microbiology 59: 383-391.

Shimp R. G., Crandall R. B. \& Crandall C. A. 1975. Heligmosomoides polygyrus ( Nematospiroides dubius): suppression of antibody response to orally administered sheep erythrocytes in infected mice. Experimental Parasilology 38: 257-269.

Sitepu P., Dosson C. \& Brindeley P. J. 1985. Immunization and immunosuppression in mice reared for high and low immunc responsiveness against Nematospiroides dubius. International Journal for Parasitology 15: 277 281 . 